Marina IVANOVA (lževsk),

Larisa Ponomarjova (Perm/Budapest) \&

Esa-Jussi Salminen (Turku)

\title{
Konferensseja komipermjakkien mailla
}

Permiläiset kielet komisyrjääni, komipermjakki ja udmurtti muistuttavat paljon toisiaan. Komisyrjääniä ja komipermjakkia voi hyvin pitää saman kielen eri murteina ja komin kansan jakamista näin kahtia vain neuvostopolitiikan tuloksena, mutta toisaalta molemmilla on oma kirjakieli. Suomalaisessa fennougristiikassa komipermjakit ovat olleet kautta aikain melko vähän esillä. Tästä tendenssistä huomattavin poikkeus on Seppo Lallukan vuonna 1995 ilmestynyt kirja Komipermjakit - perämaan kansa.

Suomalaisten fennougristien puheenaiheeksi ja suomalaisten sukukansoista kiinnostuneiden tietoisuuteen komipermjakit nousivat vuosien 2004-2005 aikoina, kun tuli tietoon hanke liittää Permin komien autonominen piirikunta Permin alueeseen. Permin komien autonominen piirikunta (eli Permin Komin autonominen piirikunta) oli suomalais-ugrilaisista kansallisista aluemuodostelmista ainoa, jossa nimikkokansallisuuteen kuului selkeä enemmistö asukkaista, 62 prosenttia. Yhdistyminen toteutui 1.12.2005 ja muodostui Permin aluepiiri. Taloudelliset ja kulttuuriset syyt sekä se, että edelleenkään piirikunnan ja Komin tasavallan välillä ei ole kunnollista maantieyhteyttä, vaikuttivat virallisten selitysten mukaan siihen, että piirikuntaa ei useiden älymystön edustajien ja tavallisen kansan toiveista huolimatta yhdistetty Komin tasavaltaan vaan Permin alueeseen. Alueliitoksen toteuduttua on jäänyt epäselväksi, mikä oikeastaan muuttui virallisesti, saati käytännössä; entiset Permin Komin autonomiseen piirikuntaan viittaavat nimikkeet ovat edelleen käytössä.

Ennen komipermjakkien pääkaupunki oli piirikunnan pääkaupunki Kudymkar. Kudymkarissa toimii Udmurtian valtionyliopiston haaraosasto ja sen suhteet, samoin kuin Permin valtiollisen pedagogisen yliopiston, etenkin permistiikan alalla ovat vilkkaat nimenomaan Udmurtian valtionyliopiston kanssa. Välimatkakin on Iževskiin hiukan lyhyempi kuin Syktyvkariin. Kudymkar on Venäjän mittakaavassa hyvin pieni, vuoden 2002 väestönlaskun mukaan noin 32000 asukkaan kaupunki. Se sijaitsee Kaman sivujokien Invan ja Kuvan rannoilla.

Perm sijoittuu Kamajoen molemmille puolin Permin alueella. Perm on ollut pitkään miljoonakaupunki, mutta viimeisimmät laskelmat osoittavat väkiluvun laskeneen miljoonan alle. Tästä lähtien Joškar-Olan, Syktyvkarin, Saranskin, Iževskin, Narjan-Marin ja muiden etäsukukansojen pääkaupunkien listaan voisi lisätä näitä kaikkia asukasluvultaan suuremman Permin, Permin aluepiirin pääkaupungin. Toisaalta Permin aluepiiri ei ole oikeastaan kansallinen aluemuodoste, eikä Perm siten varsinaisesti ole komipermjakkien pääkaupunki.

Komipermjakkien kansallisten tieteiden harjoittaminen on jäänyt miltei yksinomaan komipermjakkien itsensä harteille. Näiden tieteiden historiaan ja nykytilaan 
tarjoavat kiintoisan ikkunan konferenssit, joita alueella on viime vuosina pidetty. Tässä katsauksessa on mukana niistä kolme.

\section{Suuri kansainvälinen konferenssi Venäjän kansalliset kielet: alueellinen näkökulma. 50 vuotta Permin valtiollisen pedagogisen yliopiston komi- permjakkilais-venäläisen osaston muodostamisesta, Perm, 20.-21.I0.2005}

Konferenssin ajankohta ja teema muuttuivat aikaisemmin ilmoitetuista. Syynä tähän oli konferenssin herättämä odotettua laajempi kiinnostus sekä eri puolilla Venäjää että ulkomailla. Konferenssin julkaisu ilmestyi ajallaan jo vuoden 2005 puolella. Toivottavasti näin tapahtuu jatkossakin; esimerkiksi 1990-luvulla tärkeidenkin konferenssien julkaisut saattoivat ilmestyä useiden vuosienkin viipeellä.

Konferenssi oli omistettu Permin valtiollisen pedagogisen yliopiston komipermjakkilais-venäläisen osaston 50-vuotispäivän kunniaksi. Vuonna 1955 silloisen Molotovilaisen valtiollisen pedagogisen instituutin filologiseen tiedekuntaan perustettiin komipermjakkilais-venäläinen osasto, jossa on mahdollista suorittaa 5-vuotiset opinnot linjalla "komipermjakin kielen ja kirjallisuuden opettaja, venäjän kielen ja kirjallisuuden opettaja". Vuosina 1977-1983 toimi osastossa yleisen ja komipermjakkilaisen kielitieteen laitos. Osastossa opiskelee noin 130 opiskelijaa. Komipermjakin kieltä ja kulttuuria opettaa 4 henkeä, joiden lisäksi osastossa työskentelee lukuisia venäjän kielen ja kulttuurin tutkijoita ja opettajia. Laitoksen suomen opetuksesta vastaa Larisa Ponomarjova.

Konferenssissa oli 327 osallistujaa, joista suuri määrä, peräti 23 delegaatiota, tuli Permin alueelta. Kokonaisia delegaatioita oli myös 17:stä Venäjän federaation subjektista eli tasavalloista, piirikunnista ja muilta alueilta. Konferenssissa pidettiin yli 90 esitelmää, jotka oli jaettu 7 sektioon sekä plenaariesitelmiin. Sektioiden esitelmistä suurin osa käsitteli permiläisiä kieliä ja niistä erityisesti komipermjakkia. Kuultiinpa yksi esitelmäkin tällä kielellä, mutta muuten konferenssi oli venäjäksi. Venäjän tiedeakatemian Kielitieteen instituutissa Moskovassa työskentelevä Raisa Batalova määritteli esitelmässään komipermjakin tutkimuksen tämänhetkisiksi painopisteiksi puhekielen ja murteiden, erityisesti kuolevien murteiden tutkimisen sekä sanakirjojen laatimisen ja ortografian kysymykset.

Konferenssissa esiintyi Venäjän federaation alueellisen kehityksen ministeriön kansainvälisten suhteiden osaston päällikkö Aleksandr Sirtšenko. Sirtšenko esitti täsmällistä tilastotietoa Venäjän kansallisten kielten tilanteesta, omakielisistä lehdistä, televisio- ja radio-ohjelmista, kansallisista kouluista ym. Hän mainitsi myös M. A. Castrénin seuran merkittävänä avustajana. Täydellinen numerotieto jäi kaipaamaan analyysia; onko esimerkiksi 2000 kansallista tataarikoulua tai 8 marinkielistä lehteä vähän vai riittävästi? Kyseinen ministeriö oli aloittanut toimintansa vasta maaliskuussa 2005. Yleisön ilmaisemaan huoleen omakielisten radio- ja televisio-ohjelmien vähentymisestä Sirtšenko vastasi, että tällaiset tilanteet kannattaa ensin käsitellä paikallisella tasolla, mutta viime kädessä myös ministeriön on kannettava vastuunsa. 
Konferenssin pyöreän pöydän keskustelussa puhuttiin vuonna 1992 tehdyn, vähemmistökieliä koskevan Eurooppalaisen asiakirjan ratifioinnista. Venäjä on sen allekirjoittanut mutta ei ole sitä ratifioinut. Osa keskustelijoista oli sitä mieltä, että Venäjä ei ole vielä mitenkään valmis ratifioimaan sopimusta. Sitä voitaisiin käyttää poliittisiin tarkoituksiin Venäjää vastaan. Erityisesti tataarien edustajat puolestaan olivat voimakkaasti asiakirjan ratifioimisen kannalla. Lopuksi Sirtšenko muistutti, että Venäjällä ei tule olemaan vaikeuksia täyttää kaikki asiakirjan kohdat monien niiden kansojen osalta, joilla on oma vahva tasavalta ja suhteellisen hyvä asema jo nyt, kuten tataarit ja baškiirit. Sen sijaan vaikeuksia tulee heikommassa asemassa olevien kansojen kohdalla. Paradoksaalisesti kuitenkin pyöreän pöydän ääressä oli edustettuina useita tataareja useimpien muiden kansojen edustajien puuttuessa tyystin. Useimmat olivat yksimielisiä siitä, että pitää selvästi erottaa alueelliset kielet (ts. jonkin tietyn alueen alkuperäiset kielet) muista vähemmistökielistä.

\section{XI Kansainvälinen symposiumi Permiläisten kielten murteet ja historia vuorovaikutuksessa muiden kielten kanssa, Perm, 30.-31.3.2006}

Ensimmäisen kerran permistiikan kansainvälisten symposiumien historiassa XI symposiumi Permiläisten kielten murteet ja historia vuorovaikutuksessa muiden kielten kanssa pidettiin Permin valtiollisen pedagogisen yliopiston seinien sisäpuolella, komipermjakkilais-venäläisen osaston suojissa. Se oli omistettu tunnetun komipermjakkilaisen kielitieteilijän, vuonna 1995 kuolleen Antonina KrivoštšokovaGantmanin 85-vuotispäivän kunniaksi. Hän oli ensimmäinen komipermjakki, joka on tehnyt filologian kandidaatin väitöskirjan komipermjakin kielestä.

Symposiumiin ottivat osaa kielitieteilijät permiläisten alueiden lisäksi Unkarista ja Suomesta. Kahdessa plenaari-istunnossa ja viidessä sektiossa kuultiin yli neljäkymmentä esitelmää. Esitykset käsittelivät permiläisten kielten leksikologian, onomastiikan, dialektologian ja historian ajankohtaisia kysymyksiä. Käsiteltiin myös komipermjakin, komin ja udmurtin kielen kielioppia, kielikontakteja sekä kansallista kulttuuria. Esitelmöitsijöiden joukossa oli niin tunnettuja kielitieteilijöitä kuin myös aloittelevia tutkijoita, jatko-opiskelijoita ja opiskelijoita, joista valtaosa oli Permin valtiollisesta pedagogisesta yliopistosta ja Udmurtian valtionyliopistosta.

Esitelmät, jotka kuultiin plenaari-istunnossa, analysoivat lähinnä KrivoštšokovaGantmanin tieteellistä toimintaa. Näissä esitelmissä korostettiin hänen merkitystään, ei pelkästään permiläisten kielten tutkimukselle, vaan koko fennougristiikalle. Keskeisellä sijalla Krivoštšokova-Gantmanin toiminnassa oli ohjelmien, oppaiden ja oppikirjojen laatiminen komipermjakkilaisille kouluille äidinkielen opetusta varten. Suurin sektioista oli nimeltään "Permiläisten kielten leksikologian ja onomastiikan ongelmia", jotka olivat myös Krivoštšokova-Gantmanin pääasiallisen kiinnostuksen kohteina. Kuten professori Jelena Poljakova mainitsi, Krivoštšokova-Gantman on Kaman alueen suunnitelmallisen, systemaattisen komilaisen paikannimistön ja henkilönnimistön tutkimuksen uranuurtaja. Samoin hän laittoi alulle myös tämän nimistön kehityksen tutkimuksen ja kiinnitti huomiota siihen, miten eri kielet ovat vaikuttaneet nimistöön. 
Permiläisten kielten dialektologian ja historian kysymyksiä käsitteli 10 esitelmää. Niissä selvitettiin erilaisia komipermjakin, komisyrjäänin ja udmurtin kielen murteiden erityispiirteitä sekä synkronisesta että diakronisesta näkökulmasta. Joissakin esitelmissä käsiteltiin myös kirjakielen normeja. Kielten typologian ja kielikontaktien kysymyksiä tarkasteltiin permiläisten, itämerensuomalaisten kielten, unkarin ja venäjän kielen esimerkkien pohjalta. Permiläisten kielten morfologisista ja syntaktisista piirteistä puhuttiin sektiossa "Permiläisten nykykielten kieliopin kysymyksiä”. Joitakin permiläisten kansojen kansankulttuurin seikkoja esitettiin sektiossa "Etnokulttuurinen näkökulma permistiikassa".

Päätösplenaari-istunnossa kuultiin professori Ivan Podjukovin esitelmä, joka käsitteli komipermjakin kielen ja henkisen kulttuurin merkitystä nykyisessä etnokulttuurisessa tilanteessa Kaman alueella. Kuten tunnettua, Kaman alue on kielellisen vaihtelevuuden leimaama vyöhyke, johon on keskittynyt geneettisesti ja typologisesti erilaisia kieliä (permiläiset kielet, tataari ja venäjä).

Ennen symposiumia ilmestyi Permin valtiollisen pedagogisen yliopiston julkaisupäätöksellä Krivoštšokova-Gantmanin teosten kaksiosainen kokoelma. Symposiumin materiaalit julkaistiin teoksessa Permistika XI, joka sisältää useita artikkeleita ja katsauksia Krivoštšokova-Gantmanin tieteellisestä toiminnasta.

\section{Nuorisokonferenssi Komipermjakit ja suomalais-ugrilainen maailma: piirin tulevaisuus - nuorison vastuu, Kudymkar, 27.-29.1I.2007}

Kansainvälinen status tälle(kin) konferenssille lankesi Iževskin kautta yhdessä udmurttidelegaation kanssa tulleiden suomalaisten ja unkarilaisten esitelmöitsijöiden ansiosta. Plenaariesitelmiä kuultiin kymmenen, joista kuusi oli kudymkarilaisen pitämiä. Vaikka kaupungin oma yliopisto on vasta suunnitteilla, esitelmät vakuuttivat, että Kudymkarissa on jo nyt korkeatasoista kulttuurin ja yhteiskunnan tutkimusta.

Osa plenaariesitelmistä käsitteli nimenomaan nuorisoon liittyviä teemoja, osa taas yleisempiä teemoja, kuten komipermjakkien asemaa Permin alueella tai osana suomalais-ugrilaista maailmaa. Venäjän tiedeakatemian paikallista osastoa edustava Valeri Derjabin puhui aiheesta "Kasvavan sukupolven asema ja rooli etnokulttuurisen ympäristön säilyttämisessä’. Kudymkarin kaupungin Svetlana Aristovan mukaan nimettyä koulutuskeskusta edusti tulevaisuudentutkija Pjotr Korolev. Hänen aiheensa oli "Piirin tulevaisuus ja nuorison vastuu". Svetlana Gagarina Permin komien piirikunnan kulttuurihallinnosta piti esitelmänsä nuorisopolitiikasta. Muut plenaariesitelmöitsijät tulivat Udmurtian valtionyliopiston paikallisesta haaraosastosta, Permin komien piirikunnan hallinnosta sekä permiläisten alueiden korkeakouluista. Esitelmät olivat läpileikkaus komipermjakin kielen ja kulttuurin tutkimuksesta ja toimivat ikään kuin teoreettisena pohjana opiskelijoiden omalle sektiotyöskentelylle.

Udmurtian valtionyliopiston Kudymkarin haaraosaston tiloissa pidettiin kaikkiaan kahdeksan sektiota: talous, politologia ja oikeus; etninen historia; materiaalinen ja henkinen kulttuuri; nuoriso: nykytilanne ja tulevaisuus; suomalais-ugrilaiset kielet; suomalais-ugrilaisten kansojen kirjallisuus; innovaatiot opetuksessa ja etninen 
elokuva. Kaikkein suosituimmassa, suomalais-ugrilaisessa sektiossa käsiteltiin muun muassa udmurtin kielen käyttöä kaupunkiympäristössä sosiolingvististen kyselytutkimusten perusteella. Tällainen tutkimussuuntaus on fennougristiikassa ja yleensä Venäjällä melko uusi ja hyvin tarpeellinen. Aihe on hyvin läheinen kaikille Venäjän pienille kansoille. Kuinka voimme suojella äidinkieltämme? Tilastot näyttivät vastaansanomattomasti, että udmurtin opiskelijoiden määrä pienenee. Voiko vähemmistökansojen venäläistymistä pysäyttää ja jos voi, niin miten? Kieli pitäisi oppia luonnollisesti perheen käyttökielenä, tai sen oppiminen muulla tavoin pitäisi tehdä houkuttelevaksi ja tehokkaaksi.

Toisen päivän sektio-osuuden jälkeen kokoonnuttiin perinteisen venäjäläisen käytännön mukaan jälleen plenaari-istuntoon. Johtavana ajatuksena oli, että tällaisia suomalais-ugrilaisia kansoja yhteen kokoavia tapaamisia voisi järjestää useamminkin. Venäjän sukukansojen erittäin aktiivinen osallistuminen IFUSCOon (suomalaisugrilaisten nuorten opiskelijakonferensseihin) ja niiden järjestäminen Venäjällä jo useita kertoja viime vuosien aikana osoittavat, että nuoret opiskelijat ja tutkijanalut todella haluavat tavata toisiaan. Ehkä nuorten tapaamisissa kannattaisi joskus myös vähentää virallisten puheiden osuutta ja varata enemmän aikaa nuorten keskinäiseen kanssakäymiseen.

Marina Ivanova <marivanova@udm.ru>

Larisa Ponomarjova $<$ dojeg@mail.ru $>$

Kapás utca 31-40

HU-1027 Budapest

Esa-Jussi Salminen <e-j.salminen@suomi24.fi>

Konttitie 4 A 8

01360 Vantaa 